\title{
Iduronate Sulfatase Activity in Serum, Lymphocytes, and Fibroblasts-Simplified Diagnosis of the Hunter Syndrome
}

\author{
INGEBORG LIEBAERS AND ELIZABETH F. NEUFELD ${ }^{(27)}$ \\ National Institute of Arthritis, Metabolism, and Digestive Diseases, National Institutes of Health, \\ Bethesda, Maryland, USA
}

\section{Extract}

A previously described assay for iduronate sulfatase has been adapted for use with serum, lymphocytes, and fibroblasts. The assay also gives a rough measure of iduronidase activity. We have evaluated the procedure for the diagnosis of the Hunter syndrome, for the detection of Hunter heterozygotes, and for the diagnosis of certain other disorders (mucolipidoses II and III and mucopolysaccharidosis I).

Hunter patients had 1-2\% normal iduronate sulfatase activity in the three sources tested. The serum assay is undoubtedly the method of choice to establish the diagnosis of the Hunter syndrome. Less than $1 \mathrm{ml}$ serum and 3-4 days are required to complete the procedure.

Serum could not be used for the detection of iduronidase deficiency diseases, but these could easily be recognized in lymphocyte and fibroblast preparations.

The iduronate sulfatase activity of sera from patients with mucolipidoses II and III was elevated 20 -fold, but their parents had a normal level of this enzyme. In fibroblasts of patients with mucolipidoses II and III, both iduronate sulfatase and iduronidase activities were markedly decreased.

Serum assays were not informative about the Hunter heterozygote status. However, the mean activity in lymphocytes from mothers of Hunter patients was about half of the mean normal activity. A number of obligate heterozygotes had iduronate sulfatase activity so low that they were identifiable as carriers; others, unfortunately, had a clearly normal level. The possibility of carrier detection by the lymphocyte assay needs further development.

\section{Speculation}

The procedure described shows markedly reduced iduronate sulfatase activity in lymphocytes of half the obligate heterozygotes tested; with further refinements, it may form the basis of a carrier detection test.

The primary defect in the Hunter syndrome (mucopolysaccharidosis II) is a profound deficiency of iduronate sulfatase $(1,5$, 16). The stepwise degradation of dermatan sulfate and of heparan sulfate is interrupted at the sulfated iduronic acid residue, leading to massive accumulation of these polymers within lysosomes of most tissues; this cellular storage is presumed to be the cause of the numerous and well known clinical problems (12). In contrast to other mucopolysaccharidoses, which are inherited in autosomal recessive fashion, the Hunter syndrome is $X$-linked. Correct diagnosis of this disease is obviously essential for counseling of Hunter families.

Excessive accumulation of $\left.{ }^{[35} \mathrm{S}\right]$ mucopolysaccharide in skin fibroblasts and correction (i.e., reduction) of such abnormal accumulation by Hunter corrective factor have been the biochemical criteria used in our laboratory for several years for the diagnosis of the Hunter syndrome $(3,14)$. It is now known that the Hunter corrective factor has iduronate sulfatase activity, and that the accumulation-correction test is an indirect way to detect a total or near total deficiency of that enzyme (1). Although very reliable, the test has not been widely adopted because it requires highly purified factor and specialized techniques. Direct measurement of iduronate sulfatase activity by use of a $\left.{ }^{35} \mathrm{~S}\right]$ mucopolysaccharide substrate (1) is prone to error and is not recommended for diagnosis. On the other hand, the assay described by Lim et al. (10) is simple and reliable, and has now been adapted for use with serum, lymphocytes, and fibroblasts.

The principle of the assay is shown in Figure 1. The substrate is a radioactive disulfated disaccharide composed of a sulfated iduronic acid glycosidically linked to a sulfated anhydromannitol which has been labeled with tritium. Iduronate sulfatase cleaves the sulfate group from the iduronic acid residue, leaving a radioactive monosulfated disaccharide ( product $l$ ), which in turn serves as substrate for any $\alpha$-L-iduronidase that might be present. The iduronidase liberates radioactive anhydromannitol sulfate (product 2) and unlabeled iduronic acid. Radioactive products are separated electrophoretically from each other and from residual substrate, and are quantitated by counting.

We have evaluated this procedure for the diagnosis of the Hunter syndrome, for the detection of Hunter heterozygotes, and for the diagnosis of certain other disorders in which the level of iduronate sulfatase (mucolipidoses II and III) or of iduronidase (mucopolysaccharidosis I) is drastically altered. A preliminary account of this work has been presented $(9,14 a)$.

\section{MATERIALS AND METHODS}

\section{SUBSTRATE}

The preparation of the substrate by deaminative cleavage of heparin followed by isolation and reduction of the resulting disulfated disaccharide with $\mathrm{NaB}^{3} \mathrm{H}_{4}$ have been previously described (10). ${ }^{3} \mathrm{H}$-Labeled and unlabeled substrate were mixed to give a specific activity of $14 \mu \mathrm{Ci} / \mu \mathrm{mol}$.

\section{PREPARATION OF BIOLOGIC SAMPLES}

Serum samples prepared from $2 \mathrm{ml}$ blood were dialyzed against five baths, 6 liters each, of $0.9 \% \mathrm{NaCl}$, over a period of $20 \mathrm{hr}$ at $4^{\circ}$. No activity is detected in undialyzed serum. Protein content was determined after dialysis (11).

Lymphocytes (in fact, a mixture of lymphocytes, monocytes, 


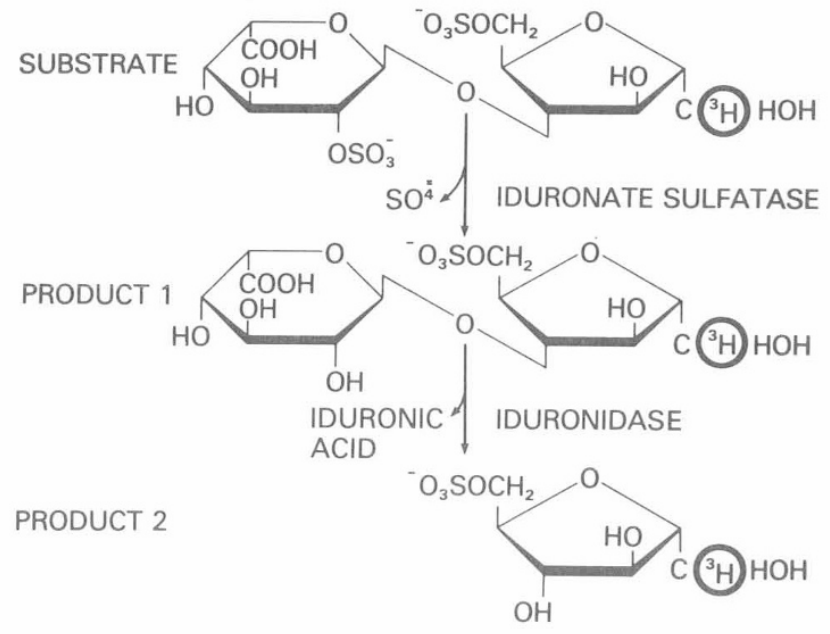

Fig. 1. Degradation of ${ }^{3} \mathrm{H}$-labeled substrate by a combination of iduronate sulfatase and $\alpha$-L-iduronidase. The substrate, $O-(\alpha-\mathrm{L}-$ idopyranosyluronic acid 2-sulfate)-( $\rightarrow 4)$-2,5-anhydro-D-[1- $\left.{ }^{3} \mathrm{H}\right]$ mannitol 6-sulfate, is schematically depicted with an un-ionized carboxyl group of uronic acid, although at the $\mathrm{pH}$ of incubations this residue is predominantly in the uronate form.

and platelets) were separated over a Hypaque-Ficoll cushion (2) from $15-\mathrm{ml}$ samples of blood collected in EDTA. Ficoll 400 was obtained from Pharmacia (17), and Hypaque (50\% sodium diazotrizoate) from Winthrop Laboratores (18). The cell layer above the Hypaque-Ficoll was removed with a Pasteur pipette and washed three times with centrifugation in $0.9 \% \mathrm{NaCl}$. The cell pellet was taken up in $0.4 \mathrm{ml} 0.9 \% \mathrm{NaCl}$ and disrupted by six cycles of freeze-thawing and a final homogenization by hand in a small homogenizer (19). The resulting homogenates were dialyzed as above, resuspended in the homogenizer, and analyzed for protein as above.

Fibroblast cultures were initiated from skin biopsies obtained in the course of diagnostic procedures, or were obtained from the Human Genetic Mutant Cell Repository (20); they were maintained as previously described (4). The cells in $75 \mathrm{~cm}^{2}$ Falcon flasks were harvested 3-4 weeks after transplantation and converted to an acetone powder as described by Hall et al. (7), except that $5 \mathrm{ml}$ acetone were used for the cell pellet from one flask. Before use, the powders were suspended in $0.9 \% \mathrm{NaCl},(0.3 \mathrm{ml} /$ original flask $)$, stirred occasionally during $1 \mathrm{hr}$ at $0^{\circ}$, and clarified by centrifugation at $10,000 \times g$ for $10 \mathrm{~min}$. The supernatant solutions were dialyzed as above and the protein was determined as above. Cultured amniotic fluid cells were handled in the same manner as cultured fibroblasts, except that they were used as soon as confluent. Informed consent was obtained before taking samples of blood or skin biopsies.

\section{ENZYME ASSAYS}

Assay conditions varied slightly for serum, lymphocytes, and fibroblasts. For convenience, a substrate mixture was prepared containing $0.27 \mathrm{M}$ sodium acetate buffer at $\mathrm{pH} 4.0$ or $4.5,13.3$ $\mathrm{mM}$ sodium azide, and $0.75 \mathrm{mM}$ substrate. The mixture at $\mathrm{pH} 4.0$ contained, in addition, $1 \mathrm{mg} / \mathrm{ml}$ bovine serum albumin.

Serum samples, $50 \mu \mathrm{l}$, were incubated with $30 \mu \mathrm{l} \mathrm{pH} 4.5$ substrate mixture in capped 1-ml polystyrene disposable test tubes (21) for $6 \mathrm{hr}$ at $37^{\circ}$. It is important to use equipment which minimizes evaporation from the incubation mixture.

Lymphocyte homogenates, $50 \mu$ l containing $100-200 \mu$ g protein, were mixed with $30 \mu \mathrm{l} \mathrm{pH} 4.0$ substrate mixture and incubated as described for serum but for $24 \mathrm{hr}$.

Fibroblast extracts, $20 \mu \mathrm{l}$ containing $10-20 \mu \mathrm{g}$ protein, were incubated with $15 \mu \mathrm{l} \mathrm{pH} 4.0$ substrate mixture in sealed capillary tubes for $24 \mathrm{hr}$ at $37^{\circ}$.
A substrate blank, containing all reagents but without the biologic sample, was incubated along with the experimental samples.

At the end of the incubation, products and residual substrate were separated from each other by electrophoresis at approximately $25 \mathrm{~V} / \mathrm{cm}$ and $275 \mathrm{ma}$ for $\mathrm{I} \mathrm{hr}$ in $1.9 \mathrm{M}$ formic acid, $\mathrm{pH} 1.7$, in a high voltage electrophorator model D (22). Whatman no. $3 \mathrm{MM}$ paper, 70 by $46 \mathrm{~cm}$, was soaked in the formic acid and blotted, and $25 \mu \mathrm{i}$ incubation mixture and substrate blank were applied in 2-cm spots. A routine marker solution, consisting of substrate and product $l$ prepared with purified iduronate sulfatase (10), was run concurrently. The location of product 2 was determined in preliminary experiments by near coincidence with galactose-6-sulfate (23), a compound of identical charge and only slightly greater molecular weight.

The separation procedure differs from the one previously described (10) in that electrophoresis is performed at higher amperage and on Whatman no. 3MM paper. This was found essential to prevent artifacts caused by the high protein content of the biologic samples, particularly of serum. Under conditions of electrophoresis or chromatography previously recommended, the substrate and products bind to the protein in variable fashion, leading to erratic results.

After drying, the paper was cut into 4-cm wide strips; the radioactive areas were located with a chromatograph scanner, cut out, and counted at $4 \%$ efficiency in a liquid scintillation spectrometer as described $(10,24)$.

The fraction of substrate hydrolyzed is a function of iduronate sulfatase activity. This fraction is calculated as: [cpm (product $1+$ product 2) $] /[\mathrm{cpm}$ (product $1+$ product $2+$ residual substrate) $]$, and is corrected for the corresponding fraction in the enzyme blank (usually about 0.03 ). This corrected value, multiplied by the amount of substrate initially present in the incubation mixture, equals the amount of substrate hydrolyzed. The activity of iduronate sulfatase is expressed as nanomoles of substrate hydrolyzed per mg protein per $24 \mathrm{hr}$. It should be pointed out that the substrate concentration used is one-tenth the $\mathrm{K}_{\mathrm{m}}(10)$. Under these conditions, the amount of substrate hydrolyzed per unit time is far from the maximum that would be observed under saturating conditions. The advantage of using the low substrate concentration is that the yield of products is relatively high. Optimal conditions include a combination of substrate concentration, time, and enzyme level such that $0.1-0.5$ of the substrate is converted to products; below one-tenth, the blank correction becomes substantial and above 0.5 , there is a marked deviation from linearity (10).

The ratio of the second product to total product formation is a rough measure of iduronidase activity. Since the iduronidase reaction is dependent on prior formation of the first product, iduronidase activity is underestimated when iduronate sulfatase is limiting, and cannot be measured at all when iduronate sulfatase is absent. The $\mathrm{pH}$ of the reaction mixtures is optimal for iduronate sulfatase, but higher than the optimum for iduronidase.

Characteristic electrophoretic patterns of residual substrate and products found at the end of incubation are shown in Figure 2.

\section{RESULTS}

The activities of iduronate sulfatase and of iduronidase of individuals of various genotypes are reported in Table 1. A number of conclusions emerge from the data.

On the basis of protein content, normal fibroblast extracts have 5 times the iduronate sulfatase activity of normal lymphocyte homogenates, which in turn have 4 times the activity of serum. However, the amount of serum used per assay corresponds to 0.1 $\mathrm{ml}$ blood, whereas the lymphocyte homogenate is derived from $0.5-2 \mathrm{ml}$.

Hunter patients had about $1-2 \%$ of normal activity in the three sources tested. It is not known whether this represents true residual activity of a defective iduronate sulfatase or the action of some other, nonspecific sulfatase. As with previous tests $(1,3)$, there was 


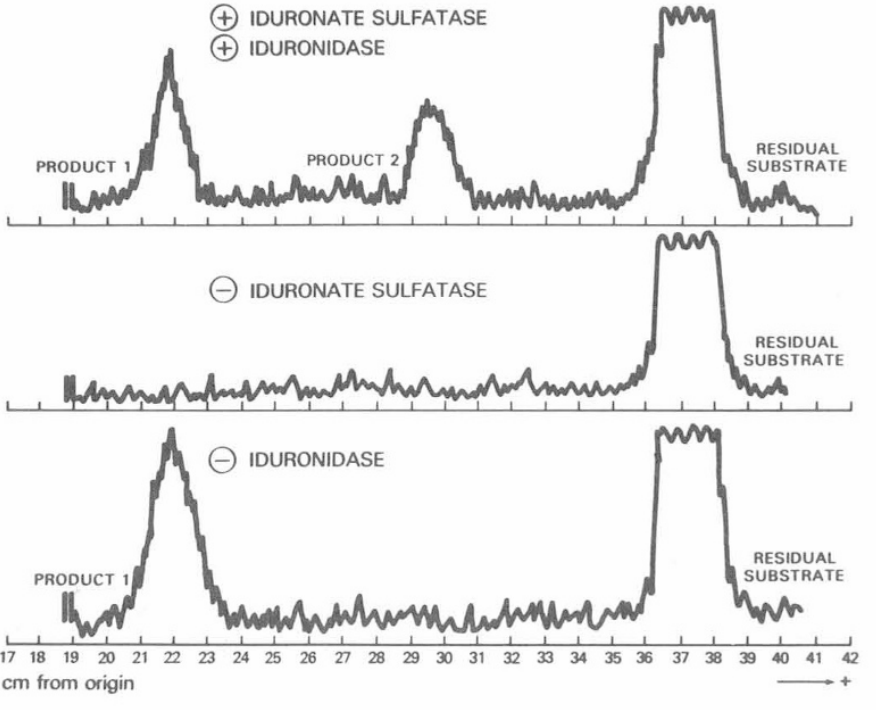

Fig. 2. Tracing of scanned electrophoretograms of incubation mixtures that include both iduronate sulfatase and iduronidase, or only one of the two.

Table 1. Iduronate sulfatase and iduronidase activities of preparations from different genotypes ${ }^{1}$

\begin{tabular}{|c|c|c|c|}
\hline \multirow[b]{2}{*}{ Genotype } & \multirow[b]{2}{*}{$n$} & \multirow{2}{*}{$\begin{array}{l}\text { Iduronate } \\
\text { sulfatase, } \\
\text { nmol/mg } \\
\text { protein } / 24 \mathrm{hr} \\
(\text { mean } \pm \text { SEM) }\end{array}$} & \multirow{2}{*}{$\begin{array}{l}\text { Iduronidase, } \\
\text { product } 2 \\
\text { products } 1+2\end{array}$} \\
\hline & & & \\
\hline \multicolumn{4}{|l|}{ Serum } \\
\hline Normal & 30 & $10 \pm 0.5$ & Not detected ${ }^{2}$ \\
\hline Hunter & 10 & $0.08 \pm 0.03$ & Not applicable \\
\hline MPS I & 5 & $12 \pm 1.0$ & Not detected \\
\hline Other MPS & 2 & $12 \pm 0.4$ & Not detected \\
\hline Mucolipidosis II & 2 & $191 \pm 53$ & Not detected \\
\hline Mucolipidosis III & 5 & $151 \pm 57$ & Not detected \\
\hline Hunter mothers & 7 & $8 \pm 0.7$ & Not detected \\
\hline $\begin{array}{l}\text { Mucolipidoses } \\
\text { heterozygotes }\end{array}$ & 4 & $12 \pm 2$ & Not detected \\
\hline \multicolumn{4}{|l|}{ Fibroblast extracts } \\
\hline Normal & 6 & $182 \pm 28$ & 0.95 \\
\hline Hunter & 8 & $2 \pm 1$ & Not applicable \\
\hline MPS I & 4 & $117 \pm 24$ & 0.02 \\
\hline Other MPS & 6 & $144 \pm 11$ & 0.96 \\
\hline Mucolipidosis II & 1 & 52 & 0.40 \\
\hline Mucolipidosis III & 2 & $20 \pm 6$ & 0.20 \\
\hline $\begin{array}{l}\text { Normal amniotic } \\
\text { fluid cells }\end{array}$ & 3 & $197 \pm 61$ & 0.46 \\
\hline \multicolumn{4}{|c|}{ Lymphocyte homogenates } \\
\hline Normal & 30 & $46 \pm 4$ & 0.63 \\
\hline Hunter & 5 & $1 \pm 0.1$ & Not applicable \\
\hline MPS I & 6 & $42 \pm 9$ & 0.01 \\
\hline Mucolipidosis II & 1 & 27 & 0.42 \\
\hline Mucolipidosis III & 3 & $29 \pm 4$ & 0.57 \\
\hline Hunter mothers & 11 & $24 \pm 6$ & 0.63 \\
\hline $\begin{array}{l}\text { Hurler hetero- } \\
\text { zygotes }\end{array}$ & 4 & $44 \pm 15$ & 0.26 \\
\hline
\end{tabular}

${ }^{1}$ MPS: mucopolysaccharidosis.

${ }^{2}$ Limit of detection $=0.02$.

no greater activity in patients with the mild form than in those with the severe form (12) of the disease.

Serum could not be used for the detection of iduronidase deficiency diseases (i.e., mucopolysaccharidosis I-the Hurler,
Scheie, and Hurler/Scheie syndromes) since iduronidase activity could not be detected in normal serum by the present assay. However, lymphocyte and fibroblast preparations from mucopolysaccharidosis I patients could easily be recognized by the absence of the second product. In spite of the imprecise nature of the iduronidase determination, lymphocytes from Hurler heterozygotes were found to have reduced activity.

The iduronate sulfatase activity of sera from patients with mucolipidoses II (I-cell disease) and III (pseudo-Hurlerpolydystrophy) was greatly elevated (20-fold), as are many other lysosomal enzymes (see review, Reference 15). In those patients serum iduronidase was also increased, since it was clearly detectable when undiluted serum was used, although not when the serum was appropriately diluted to keep iduronate sulfatase activity within linear range. In fibroblasts, both iduronate sulfatase and iduronidase activities of patients with mucolipidoses II and III were markedly decreased, again in keeping with a number of other lysosomal enzymes (15). However, there was only partial reduction of either enzyme in lymphocytes of the same patients. Mucolipidoses II and III heterozygotes had a normal level of iduronate sulfatase activity in serum.

Patients with mucopolysaccharidoses because of a deficiency of other enzymes had normal iduronate sulfatase and iduronidase activities.

Serum assays were not informative about the Hunter heterozygote status, since the mean activity of sera from seven Hunter mothers (including one who had more than one affected child) was indistinguishable from the normal mean. Fibroblasts from heterozygotes were not studied extensively because of their tendency to self-clone in culture. However, the mean activity in lymphocytes from mothers of Hunter patients was about half of the mean normal activity.

This observation is examined in greater detail in Figure 3. Values obtained for mothers of Hunter patients with only one affected child are separated from values obtained for mothers with two affected children or with a family history. Only the latter are considered obligate heterozygotes, since the former might include cases of sporadic mutations. A number of heterozygotes had iduronate sulfatase so low that they were identifiable as carriers by the enzyme test; others, unfortunately, had a clearly normal level,

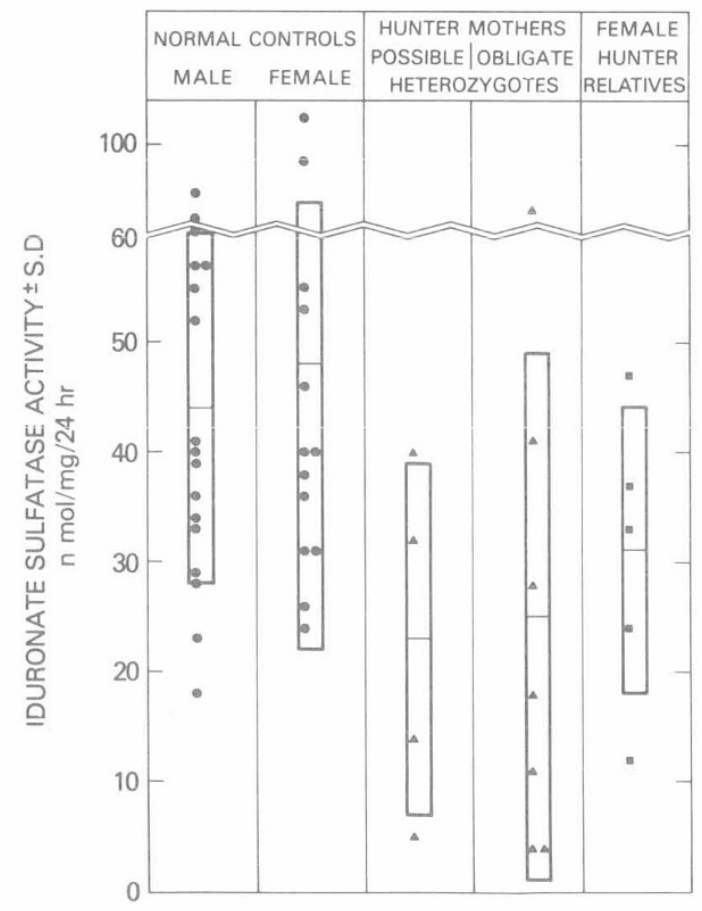

Fig. 3. Iduronate sulfatase activity in normal individuals and in Hunter heterozygotes. 
and one obligate heterozygote even had a markedly elevated level. (So did a few normal subjects. The cause of the elevated levels is not known; it is probably not the result of polymorphism, but rather of a transient problem, since the normal individual who had the highest level when first tested had normal activity when lymphocytes were prepared 6 months later). The possible heterozygote status of the Hunter mother with the lowest enzyme activity, plotted in Figure 3, was confirmed by cloning her fibroblasts and finding both normal and Hunter clones (13).

A few close female relatives (sisters and aunts) of Hunter patients were also tested; two of these had activity so low that they may be presumed to be heterozygotes.

\section{DISCUSSION}

The serum assay is undoubtedly the method of choice to establish the diagnosis of the Hunter syndrome. Less than $1 \mathrm{ml}$ serum is required; the enzyme is stable in the frozen state for years, so that a diagnosis may be established retrospectively for deceased patients. Plasma may also be used, although in that case the normal values may differ somewhat from those reported in Table 1. The time required for a biochemical diagnosis is $3-4$ days when serum is used, instead of the 4-6 weeks needed if fibroblasts cultures are to be established. This reduction in waiting time is particularly valuable when the biochemical diagnosis of the patient is requested in conjunction with a prenatal diagnosis for a close relative.

The assay was originally developed for use with extracts of fibroblasts; however, we found it more laborious than the $\left[{ }^{35} \mathrm{~S}\right] \mathrm{mu}$ copolysaccharide accumulation and correction procedure, primarily because of the preparation of acetone powders. Nevertheless, it is of interest that cultured fibroblasts and amniotic fluid cells have a high level of enzyme activity. We have used the presence of iduronate sulfatase activity in cultured amniotic fluid cells as confirmation of normal results obtained by other methods. Further experience is needed to determine the reliability of the enzyme assay for prenatal diagnosis.

Detection of iduronidase deficiency diseases by the present assay is possible, but presents no obvious advantages over established procedures (8) except in those occasional instances where the information is obtained in the course of testing for the Hunter syndrome.

The possibility of carrier detection by the lymphocytes assay needs further development. It is clear that at the present time, half of the obligate heterozygotes have enzyme activity well within the normal range. This number may be reduced by technical improvements. However, certain genetically heterozygous women may remain undetectable by biochemical tests. This would occur if some selective advantage in favor of their cells with an active paternal X-chromosome has left them with predominantly normal somatic cells, rather than the mixture of normal and Hunter cells predicted by the Lyon hypothesis $(6,13)$.

\section{SUMMARY}

Profound deficiency of iduronate sulfatase activity is found in serum, lymphocytes, and fibroblasts of Hunter patients by a new assay procedure. Serum samples are especially useful for diagnostic purposes. The assay also reveals a marked increase of iduronate sulfatase in the serum, and a deficiency in the fibroblasts, of patients with mucolipidoses II or III. The same assay detects
$\alpha$-L-iduronidase activity (and the corresponding deficiency state) in normal lymphocytes and fibroblasts, although not in serum. Lymphocytes of Hunter heterozygotes have half of normal activity on a statistical basis, but the scatter is so great that only half the obligate heterozygotes can presently be identified by the test.

\section{REFERENCES AND NOTES}

1. Bach, G., Eisenberg, F., Jr., Cantz, M., and Neufeld, E. F.: The defect in the Hunter syndrome: Deficiency of sulfoiduronate sulfatase. Proc. Nat. Acad. Sci. U. S. A., 70: 2134 (1973).

2. Böyum, A.: Isolation of mononuclear cells by one centrifugation and of granulocytes by combining centrifugation and sedimentation at $1 \mathrm{~g}$. Scand. J. Clin. Lab. Invest., 21 (suppl. 97): 77 (1968).

3. Cantz, M., Chrambach, A., Bach, G., and Neufeld, E. F.: The Hunter corrective factor. J. Biol. Chem., 247: 5456 (1972).

4. Cantz, M., Kresse, H., Barton, R. W., and Neufeld, E. F.: Corrective factors for inborn errors of mucopolysaccharide metabolism. Methods Enzymol., 28: 884 (1972).

5. Coppa, G. V., Singh, J., Nichols, B. L., and DiFerrante, N.: Urinary excretion of disulfated disaccharides in Hunter syndrome: Correction by infusion of a serum fraction. Anal. Lett., 6: 225 (1973).

6. Danes, B. S., and Bearn, A. G.: Hurler's syndrome: A genetic study of clones in cell culture with particular reference to the Lyon hypothesis. J. Exp. Med., 126: 509 (1967).

7. Hall, C. W., Cantz, M., and Neufeld, E. F.: A $\beta$-glucuronidase deficiency mucopolysaccharodisis: Studies in cultured fibroblasts. Arch. Biochem. Biophys., 155: 32 (1973).

8. Hall, C. W., and Neufeld, E. F.: $\alpha$-L-Iduronidase activity in cultured skin fibroblasts and amniotic fluid cells. Arch. Biochem. Biophys., 158: 817 (1973).

9. Liebaers, I., and Neufeld, E. F.: Iduronate sulfatase in serum and lymphocytes of Hunter patients. Abstract presented at the Twenty-seventh Annual Meeting of the American Society of Human Genetics. Amer. J. Hum. Gen., 27: 59A (1975)

10. Lim, T. W., Leder, I. G., Bach, G., and Neufeld, E. F.: Assay for iduronate sulfatase. Carbohyd. Res., 37: 103 (1974).

11. Lowry, O. H., Rosebrough, N. J., Farr, A. L., and Randall, R. J.: Protein measurement with the Folin phenol reagent. J. Biol. Chem., 193: 265 (1951).

12. McKusick, V. A.: Heritable Disorders of Connective Tissue, Ed. 4, pp. 521-681 (C. V. Mosby, St. Louis, 1972).

13. Migeon, B., and Neufeld, E. F.: In preparation

14. Neufeld, E. F., and Cantz, M. J.: Corrective factors for inborn errors of mucopolysaccharide metabolism. Ann. N. Y. Acad. Sci., 179: 580 (1971).

14a. Neufeld, E. F., Liebaers, I., and Lim, T. W.: Iduronate sulfatase determination for the diagnosis of the Hunter syndrome and the detection of the carrier state. In: B. W. Volk and L. Schneck: Current Trends in Sphingolipidoses and Allied Disorders, Vol. 68, p. 253 (Plenum Press, New York, 1976).

15. Neufeld, E. F., Lim, T. W., and Shapiro, L. J.: Inherited disorders of lysosomal metabolism. Ann. Rev. Biochem., 44: 357 (1975).

16. Sjöberg, I., Fransson, L. A., Matalon, R., and Dorfman, A.: Hunter's syndrome-A deficiency of L-idurono-sulfate sulfatase. Biochem. Biophys. Res. Commun., 54: 1125 (1973).

17. Piscataway, N. J.

18. New York, N. Y.

19. Duall 20 , Kontes Glass, Vineland, N. J.

20. Institute for Medical Research, Camden, N. J

21. Fisher Scientific, Silver Spring, Md.

22. Gilson Medical Electronics, Middletown, Wisc

23. Miles Laboratories, Elkhart, Ind.

24. After submission of this paper, we developed a procedure for separating substrate and products on minicolumns of an anion exchange resin, before counting in a scintillation spectrometer. The alternative procedure does not require the costly equipment for electrophoresis and scanning. A protocol will be supplied on request.

25. We thank the numerous physicians who sent us samples of serum and skin biopsies; Dr. Jaclyn Vidgoff (Department of Pediatrics, University of Oregon) and Dr. Lalit Ambani (Department of Human Genetics, Yale University) for preparing and sending lymphocytes from several Hunter families.

26. Dr. I. Liebaers is recipient of a United States Public Health Service International Fellowship and a Belgian Nationaal Fonds voor Wetenshappelijk Onderzoek Fellowship.

27. Requests for reprints should be addressed to: Dr. E. F. Veufeld, National Institute of Arthritis, Metabolism, and Digestive Diseases, National Institute of Health, Bethesda, Md. 20014 (USA).

28. Accepted for publication February 17, 1976. 